\title{
Fluorescent pseudomonads from plant rhizosphere as biological agent to control white root disease and growth-promoting on rubber plants
}

\author{
HUSDA MARWAN", SRI MULYATI, S. SARMAN, ISLAH HAYATI \\ Program of Agroecotechnology, Faculty of Agriculture, Universitas Jambi. Jl. Jambi-Muara Bulian Km 15, Muaro Jambi 36361, Jambi, Indonesia. \\ Tel./fax.: +62-741-583051, •email: husda_marwan@unja.ac.id
}

Manuscript received: 6 September 2020. Revision accepted: 22 October 2020.

\begin{abstract}
Marwan H, Mulyati S, Sarman S, Hayati I. 2020. Fluorescent pseudomonads from plant rhizosphere as biological agents to control white root disease and growth-promoting on rubber plants. Biodiversitas 21: 5338-5343. White root disease (Rigidoporus lignosus) is a serious problem of rubber plantation in Indonesia, including in Sumatera. The fungal infection is often difficult to detect, infection develops rapidly and can cause plant death if left untreated since the early stage, and thus using biological agents might be an efficient way to overcome the disease. This research was aimed to explore fluorescent pseudomonads from rubber plant rhizosphere that can inhibit the growth of the fungal pathogen, characterize fluorescent pseudomonads isolated as biological control agent and plant growth promoter, and apply the isolate to rubber plants to control the disease and growth of plants. Twelve out of the 76 fluorescent pseudomonads isolated from several rhizospheres of rubber plants were found to be antagonistic to white root fungi. Fluorescent pseudomonads have various characteristics such as chitinolytic activity, phosphate solvent, and nitrogen fixation. The application of the antagonistic isolates on rubber seedlings was able to increase growth and suppress the colonization of $R$. lignosus on rubber plant roots.
\end{abstract}

Keywords: Biological control, pseudomonads, rhizobacteria, Rigidoporus lignosus

\section{INTRODUCTION}

White root disease is one of the obstacles in rubber plantations in Indonesia. The disease is caused by a fungus Rigidoporus lignosus (Nandris et al. 1987). This disease can result in plant death, thus reducing in production. The area of white root disease attacks in Indonesia was around 26.000 ha with an estimated yield loss of IDR 75.67 billion (Directorate General of Plantations 2016).

The initial stage of white root fungal infection is often difficult to detect because the initial location of the infection is below the soil surface, and if the plant is left untreated the infection develops rapidly and causes death (Mohd et al. 2009). The disease sign (rhizomorphs) are developed and only visible in late season. The disease cycle involves infection and colonization of fungi mycelia as primary inoculums on the root systems of rubber plant seedlings growing from stumps of infected forest trees. The fungus attack roots and collar regions of taproot causing white root rot. The growth of pathogens may progress from infected trees (second inoculum) to roots as well as healthy rubber surrounding them. The pathogen mycelia can grow about $2.5 \mathrm{~m}$ per year (Nandris et al. 1987; Kaewchai and Soytong 2010). These cause management of white root fungus disease often unable to suppress disease progression as there is difficulty in assessing the pathogens that have colonized plant roots. Early inoculation of beneficial rhizobacteria in rubber plants can protect plant roots from white root fungal infection.

The rhizosphere was defined as the zone around the root where microorganisms and processes important for plant growth and health are located (Bakker et al. 2013).
Many plant rhizospheres are inhabited by microbial groups that colonize the surface of plant roots. This zone is rich in nutrients when compared with the bulk soil due to the accumulation of a variety of plant exudates, such as amino acids and sugars, providing a rich source of energy and nutrients for bacteria. The plant-associated microbiomes consist of beneficial organisms like plant growthpromoting (Beneduzi et al. 2012; Herrmann et al. 2016; de Vrieze et al. 2018) and biocontrol agents (Mohanram and Kumar 2019).

Rhizobacteria colonize the rhizosphere, the rhizoplane (root surface), or the root itself (within radicular tissues) (Gray and Smith 2005). Bacteria of diverse genera have been identified as Plant Growth Promoting Rhizobacteria (PGPR), of which Bacillus and Pseudomonas spp. are predominant. The genera of Bacillus and Pseudomonas are well known for their antagonistic effects and their ability to trigger Induce Systemic Resistance (ISR) (Beneduzi et al. 2012; Pieterse et al. 2014). Fluorescent pseudomonads are suppressed the soil-borne pathogens through rhizosphere colonization, antibiosis, iron chelation by siderophore production and ISR (Vanitha and Ramjegathesh 2014).

The use of biological control agents on rubber seedlings prior to planting can be carried out to protect rubber plant roots from early white root fungus infection. Fluorescent pseudomonads are one of rhizobacteria that have the potential to grow as biological control agents against plant pathogenic fungi. Fluorescent pseudomonads are suitable for application as biological control agents due to their abundant population in natural soils and plant root systems and their capability to utilize many plant exudates as nutrient (Panpatte et al. 2019). This group of bacteria has 
been reported to be able to inhibit the growth of several plant pathogenic fungi, such as Fusarium oxysporum f. sp. lycopersici in tomato (Manikandan et al. 2010), Colletotrichum gloeosporioides strains in pepper (Anees et al. 2019), and Rigidoporus sp. in rubber plant (Hasanuddin 2011; Nasrun and Nurmansyah 2015; Damiri et al. 2019).

This study aims to: (i) explore fluorescent pseudomonads from rubber plant rhizosphere, which can inhibit the growth of the fungus $R$. lignosus: (ii) isolation of fluorescent pseudomonads which has characters that promote plant growth; (iii) utilize the antagonistic fluorescent pseudomonads isolate on rubber plants as biological control agent.

\section{MATERIALS AND METHODS}

\section{Isolation of fluorescent pseudomonads bacteria from rubber plant rhizosphere}

Soil samples were taken from the rubber plantation of PT. Lestari Asri Jaya, Tebo District (Jambi Province, Indonesia) and smallholder rubber plantations in Muaro Jambi District. The soil samples were obtained from the rhizosphere of well-grown rubber plants among several symptomatic plants. A total of $50 \mathrm{~g}$ of soil samples were suspended in $450 \mathrm{ml}$ of sterile distilled water in an Erlenmeyer and shake at a speed of $150 \mathrm{rpm}$ for 30 minutes (Khaeruni et al. 2010). After deposited, $1 \mathrm{ml}$ of the supernatant was taken and diluted. A total of each $0.1 \mathrm{ml}$ of $10^{-7}$ and $10^{-9}$ dilutions were spread (platting) using glass beads on King's B medium which was specific for the fluorescent Pseudomonas bacteria group. The inoculated plate was then incubated for 48 hours at room temperature. The bacteria that grew on the media were observed under UV light, fluorescent colonies were a group of fluorescent Pseudomonas bacteria, and then transferred to the new King's B media (Vanitha and Ramjegathesh 2014).

\section{Inhibition test of fluorescent pseudomonads isolates against Rigidoporus lignosus}

Rigidoporus lignosus obtained from the Laboratory of Plant Diseases, Faculty of Agriculture, Jambi University, was cultured on Potato Dextrose Agar (PDA) and incubated for 7 days until the fungal mycelium had covered the PDA surface on the Petri dish.

Fluorescent pseudomonads isolates were tested for their ability to inhibit the growth of the fungus $R$. lignosus on PDA media with a dual culture method. Bacterial isolates were streaked with a distance of $3 \mathrm{~cm}$ from the edge of the plate on the PDA medium and $3 \mathrm{~cm}$ from the pieces of the fungal colony $(0.5 \mathrm{~cm}$ in diameter $)$. The cultures were incubated at room temperature for 4 days. Observations were made on the diameter of the fungal colony $R$. lignosus. The percentage of bacterial inhibition against $R$. lignosus was calculated using the following formula.

$$
\mathrm{I}=\frac{R 1-R 2}{R 1} \times 100 \%
$$

Where:
I: Percentage of inhibition (\%)

$\mathrm{R} 1$ : Colony radius of $R$. lignosus which grows in the opposite direction to the bacteria

$\mathrm{R} 2$ : Colony radius of $R$. lignosus which grow towards the bacteria

\section{Characterization of fluorescent pseudomonads isolates}

Characterization was carried out to determine some of the physiological properties of fluorescent pseudomonads isolates which relate to their potential as biological control agents and plant growth promoters, namely hypersensitivity reactions, chitinolytic activity, phosphate solvents, and nitrogen fixation. Characterization was also carried out on isolates that showed inhibitory power against the fungus $R$. lignosus.

Hypersensitivity test was performed by infiltrating the suspension of each bacterial isolate into tobacco leaves (Nicotiana tabacum L.) at 2-3 months of age as indicator. Pseudomonads fluorescent bacteria isolate, Xanthomonas oryzae pv. oryzae (as a pathogen control) was cultured on Nutrient Broth (NB) medium for 48 hours. As much as 0.1 $\mathrm{ml}$ (population $10^{8}$ cells $/ \mathrm{mL}$ ) of each bacterial suspension was taken using a $1 \mathrm{ml}$ syringe (without a needle) then infiltrated into the lower surface of tobacco leaf slowly until the bacterial culture does not enter in leaf tissue. Hypersensitivity symptoms were observed 48 hours after inoculation. Leaves experiencing hypersensitivity symptoms showed a change in leaf color from green to yellowish (necrotic) in the inoculation area. The necrotic symptom indicates that the inoculated bacteria had the potential to become plant pathogens or have a positive reaction. In contrast, bacteria that react negatively do not show necrotic symptoms in tobacco leaves or not pathogenic to plants. The chitinolytic activity of isolates was tested using Lingappa and Lockwood method (1962). Chitin agar containing $0.2 \%$ colloidal chitin ( $\mathrm{pH}$ 6.2) was sterilized, and then poured into a Petri dish $(9 \mathrm{~cm}$ diameter). After the agar was frozen, Whattman filter paper with a diameter of $6 \mathrm{~mm}$ was placed on the surface of the agar medium. A total of $5 \mu \mathrm{l}$ of liquid culture of each bacterial isolate (population 108 cells $/ \mathrm{mL}$ ) was poured onto filter paper, and then incubated at room temperature. This procedure was repeated twice. Observations were made on the clear zone formed around the filter paper after incubation for 7 days. A chitinolytic property of bacteria was expressed by measuring isolate's chitinolytic index (CI), ratio between diameter of clear zone (purple color), and diameter of bacterial colony (Zhou et al. 2002).

The ability of the fluorescent pseudomonads isolates as a phosphate solvent was tested by growing bacterial culture on Pikovskaya media (Paul and Sinha 2016). The Pikovskaya media was poured into $15 \mathrm{~mL}$ Petri dishes and then placed Whatman paper with a diameter of $6 \mathrm{~mm}$ on the media surface. A total of $5 \mu \mathrm{L}$ of bacterial suspension (population $10^{8} \mathrm{cfu} / \mathrm{ml}$ ) was inoculated on filter paper using a micropipette, and then incubated at room temperature. Clear zone measurements were carried out up to 7 days after incubation. The halo zone formations around the growing colony show a sign of phosphate solubilization. The soluble index was evaluated according to the ratio of 
the total diameter (colony + halo zone) and the colony diameter (Edi-Premono et al. 1996).

The ability of pseudomonads fluorescent isolates to fix nitrogen was tested by growing bacterial cultures on Biological Nitrogen Fixation (BNF) media in test tubes. BNF media that already contains the bacteria culture was shaken at a speed of $120 \mathrm{rpm}$ at room temperature for 48 hours (Harca et al. 2014). Observations were made by observing the turbidity of the BNF media. If the BNF medium turns cloudy, the tested isolates are able to fix nitrogen.

\section{Application of fluorescent pseudomonads test on rubber plants}

Fluorescent pseudomonads isolates that were able to inhibit the growth of the fungus $R$. lignosus with different characteristics were applied to rubber seedlings, using a randomized block design (RBD). Healthy plants were used as negative control (plants without bacterial isolate and $R$. lignosus), and diseased plant as positive control (Plants inoculated with $R$. lignosus). A total of 20 rubber seeds were used for each treatment.

One-month-old rubber seedlings roots were soaked in a bacterial suspension for 6 hours (Marwan 2011). The seedlings were planted on soil media (a total of $5 \mathrm{~kg}$ of humic soil and $500 \mathrm{gr}$ of sterile manure) in a polybag. Two pieces of block rubber woods measuring $2 \times 2 \times 5 \mathrm{~cm}$ were placed next to each seedling. The woods were pretreated with $R$. lignosus. The plants were acclimated for 1 month before being placed in the field of experiment.

Observations were made on plant growth variables (number of leaves, stem height, stem diameter), root weight, and the percentage of colonization of the fungus $R$. lignosus. Observations of plant growth were carried out every 3 months after planting until the plants were 9 months old. Colonization of $R$. lignosus was observed 9 months after planting by dismantling all the plants, and then the roots were cleaned with running water and weighed to determine the root weight. The data for observing the growth of rubber plants was carried out by analysis of variance (ANOVA) and the Duncan Multiple Range Test at the $5 \%$ level.

\section{RESULTS AND DISCUSSION}

\section{Pseudomonas fluorescent bacteria from rubber plant}

A total of 76 isolates of fluorescent pseudomonads were observed, based on single colony testing. A single colony of fluorescent pseudomonads showed a yellowishgreen color of fluorescent pigment under ultraviolet light (Figure 1.A). The 12 antagonist isolates showed a percentage of inhibition $15.8-61.9 \%$ (Table 1). The fluorescent pseudomonads antagonist was able to inhibit the growth of the fungal mycelium $R$. lignosus and a clear zone was formed between the fungal colony and the fluorescent pseudomonads colony (Figure 1.B).

Table 1. Antagonistic ability of fluorescent pseudomonads isolates against Rigidoporus lignosus and hypersensitivity reactions on tobacco leaves

\begin{tabular}{ccc}
\hline $\begin{array}{c}\text { Fluorescent } \\
\text { pseudomonads } \\
\text { isolates code }\end{array}$ & $\begin{array}{c}\text { Inhibition } \\
\text { against } \boldsymbol{R} . \\
\text { lignosus } \mathbf{( \% )}\end{array}$ & $\begin{array}{c}\text { Hypersensitivity } \\
\text { reactions }\end{array}$ \\
\hline A1P13 & 45.8 & Negative \\
A1P26 & 61.9 & Negative \\
A2P13 & 46.7 & Negative \\
A2P16 & 41.5 & Negative \\
A3P4 & 43,7 & Negative \\
A4P15 & 17.1 & Negative \\
A4P16 & 15.8 & Negative \\
A5P3 & 31.6 & Negative \\
A5P3 & 40.8 & Negative \\
K2P5 & 16.8 & Negative \\
K3P6 & 17.1 & Negative \\
K4P9 & 15.8 & Negative \\
\hline
\end{tabular}
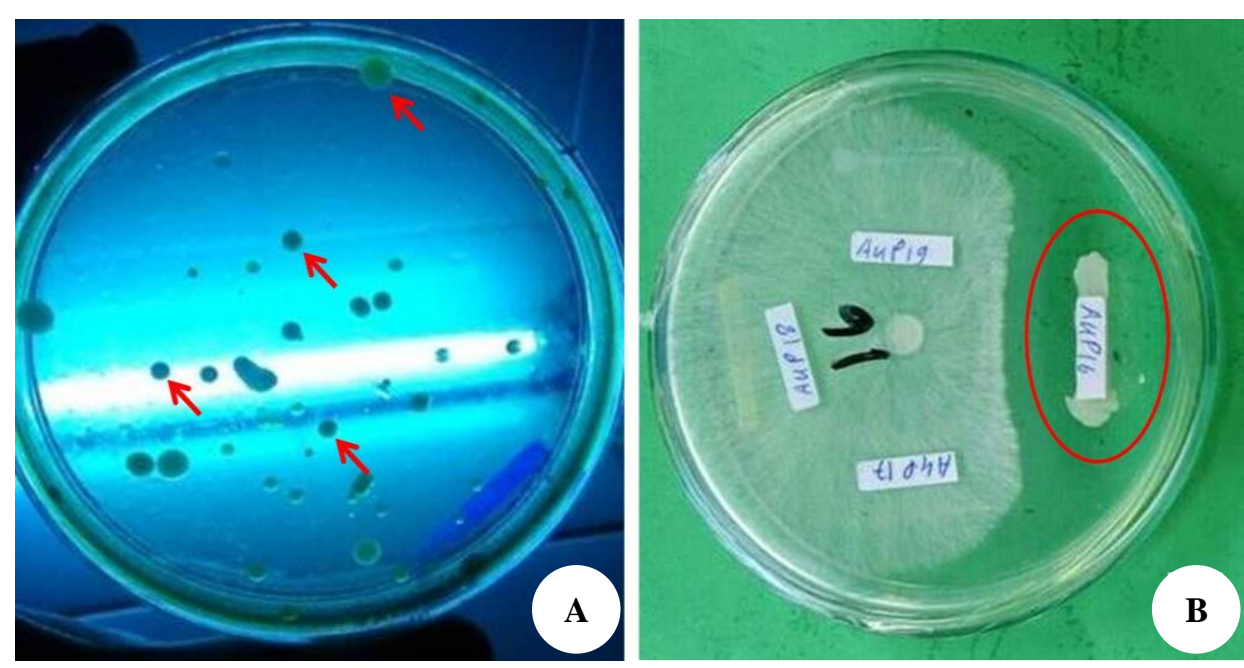

Figure 1. Isolation and selection of pseudomonads fluorescent against the fungus Rigidoporus lignosus: A. Single colony of fluorescent pseudomonads (red arrow) on Kings' medium observed under UV lamp; B. Pseudomonads fluorescent isolate which is able to inhibit the growth of $R$. lignosus (inside the red circle) 
Table 2. Characteristics of fluorescent pseudomonads antagonists against Rigidoporus lignosus

\begin{tabular}{lccc}
\hline $\begin{array}{c}\text { Fluorescent } \\
\text { pseudomonads } \\
\text { isolates code }\end{array}$ & $\begin{array}{c}\text { Chitinolytic } \\
\text { activity }(\mathbf{C I})^{\mathbf{1})}\end{array}$ & $\begin{array}{c}\text { Phosphate } \\
\text { solubility (SI) } \\
\text { 2) }\end{array}$ & $\begin{array}{c}\text { Nitrogen } \\
\text { fixation }\end{array}$ \\
\hline A1P13 & 2.14 & 3.54 & No \\
A1P26 & 2.67 & 3.79 & No \\
A2P13 & 0 & 3.33 & No \\
A2P16 & 0 & 3.25 & No \\
A3P4 & 2.04 & 3.58 & No \\
A4P15 & 3.49 & 2.71 & No \\
A4P16 & 3.71 & 2.54 & No \\
A5P3 & 3.38 & 3.46 & Yes \\
A5P3 & 0 & 2.92 & Yes \\
K2P5 & 3.25 & 2.04 & Yes \\
K3P6 & 4.08 & 2.13 & Yes \\
K4P9 & 4.75 & 0 & Yes \\
\hline Note: ${ }^{1)}$ CI: Chitinolytic index, ${ }^{2)}$ SI: Solubilization index
\end{tabular}

The ability of the fluorescent pseudomonads to inhibit the growth of the fungus $R$. lignosus was related to antifungal compounds, such as chitinolytic enzymes, produced by these bacteria. The results showed that all isolates inhibiting the growth of $R$. lignosus showed chitinolytic activity, except A2P13, A2P16, and A5P3 isolates (Table $2)$. The existence of chitinolytic activity indicates that bacteria produce enzymes that play a role in degrading chitin compounds as constituents of fungal cell walls. Chitin degradation is an important biological control mechanism for the fungal phytopathogens. Chitin is a major structural polysaccharide and is abundant in the cell walls of the majority of fungi. The $\beta-1-4$ glycosidic bonds in chitin are responsible for the cell wall integrity and are targeted by chitinases, the chitin degrading enzymes (Beier and Bertilsson 2013). The chitinolytic bacterial strains $P$. fluorescens Pf1 inhibited the mycelia growth of Alternaria solani by $43-48 \%$, Fusarium oxysporum by $30-49 \%$ (Manikandan et al. 2010) and P. fluorescens HN1205 inhibited the colony growth of Colletotrichum gloeosporioides ranging from $28-41 \%$ (Anees et al. 2019).

Results indicated that the chitinolytic index value among isolates was not related to the percentage of bacterial inhibition against the growth of R. lignosus. K4P9 isolate with the highest chitinolytic index value (4.75) was only able to inhibit the growth of R. lignosus by $15.8 \%$, in contrast, to isolate A1P26 with the highest inhibitory power $(61.9 \%)$, only has a chitinolytic index value of 2.67 . This shows that the ability of fluorescent pseudomonads to inhibit fungal growth was not only determined by chitinolytic activity. According to Haas and Defago (2005), fluorescent Pseudomonad strains that effectively suppress root diseases caused by soil-borne fungi were able to synthesize one or several antibiotic compounds. Several antibiotics that function in fungal suppression, were the phenazines (PHZ), phloroglucinols (PHL), for eg, 2, 4diacetylphloroglucinol (2,4-DAPG), pyoluteorin (PLT), pyrrolnitrin, hydrogen cyanide (HCN), and non-ribosomal peptides (NRPs) including cyclic lipopeptides (Michelsen and Stougaard 2011). Hernandez-Leon et al. (2015) reported that the P. fluorescens UM16, UM240, UM256, and UM270 strains exhibited several antifungal traits (potential presence of phenazines, DAPG, HCN, ACC deaminase, production of biofilm, IAA, siderophores, and proteases), which could be acting during the antagonism toward Botrytis cinerea.

Fluorescent pseudomonads isolates which showed antagonistic ability against $R$. lignosus have several characters in common (Table 2). Based on the hypersensitive reaction test, 12 antagonist isolates did not show necrosis in tobacco leaves so they were included in the negative hypersensitive group. A total of 3 bacterial isolates (A3P5, K2P5, K3P6) showed chitinolytic activity, phosphate solvent, and nitrogen fixation. Whereas, 5 isolates (A1P13, A1P26, A3P4, A4P15, A4P16) showed chitinolytic activity and phosphate solvent, 3 isolates (A2P13, A2P16, A5P3) as a phosphate solvent, while K4P9 showed chitinolytic activity and nitrogen fixation.

The diversity of characters of fluorescent pseudomonads antagonists isolated from several rubber plant rhizospheres can be influenced by differences in land vegetation, land management, types of rubber plants cultivated, and the interaction between microbes in the rhizosphere. According to Ross et al. (2000), the rhizosphere has indicated that individual plants harbor mixed populations of pseudomonads, many of which can suppress plant pathogens in vitro. Diverse plant host and their rhizosphere microbes can secrete multiple metabolites that can alter gene expression and the physiology of biocontrol pseudomonads (Pierson and Pierson 2007). Phase variation in some pseudomonad populations can regulate secretion of secondary metabolites that can play role in plant-pathogen suppression (van den Broek et al. 2003).

Application of fluorescent pseudomonads antagonists to rubber seedlings before planting was able to maintain plant growth on planting media infested by $R$. lignosus. Results showed that fluorescent pseudomonads treatment before planting had an effect on plant height and root weight at 9 months after planting, but had no effect on plant stem diameter (Table 3). Treatment of isolates A1P13, A4P16, and K4P9 consistently showed that plant height, stem diameter and root weight were not significantly different from the positive control treatment.

Fluorescent pseudomonads can affect plant growth directly and indirectly. Fluorescent pseudomonads have a direct effect on growth occurs because bacteria are able to provide the compounds needed for plant growth. This is related to the ability of bacteria to dissolve phosphate, fix nitrogen, and produce various plant growth hormones. Species of fluorescent pseudomonads are known to produce phytohormones like indole-acetic acid (IAA), cytokinins, gibberellins, and inhibitors of ethylene production, which may indirectly help in increasing the absorptive surface of plant roots for uptake of water and nutrients. Fluorescent pseudomonads may act directly on the growth and physiological and nutritional status of the plant they colonize (Nihorimbere et al.. 2011). 
Table 3. Effect of fluorescent pseudomonads application on rubber plant growth and mushroom colonization of Rigidoporus lignosus at 9 months after planting

\begin{tabular}{|c|c|c|c|c|}
\hline $\begin{array}{l}\text { Fluorescent } \\
\text { pseudomonads } \\
\text { isolates code }\end{array}$ & $\begin{array}{l}\text { Plant } \\
\text { height } \\
\left.(\mathbf{c m})^{*}\right)\end{array}$ & $\begin{array}{c}\text { Plant stem } \\
\text { diameter } \\
(\mathbf{m m}) \mathbf{n s})\end{array}$ & $\begin{array}{c}\text { Root } \\
\text { weight } \\
(\text { gram)*) }\end{array}$ & $\begin{array}{c}\text { Root } \\
\text { colonization by } \\
R \text {. lignosus } \\
\left.(\%)^{*}\right)\end{array}$ \\
\hline Positive control & $89.0 \mathrm{a}$ & 7.4 & $17.1 \mathrm{~b}$ & 0 \\
\hline Negative control & $75.1 \mathrm{~d}$ & 6.8 & $13.8 \mathrm{c}$ & 65 \\
\hline A1P13 & $90.2 \mathrm{a}$ & 7.5 & $23.2 \mathrm{a}$ & 0 \\
\hline A1P26 & $79.5 \mathrm{c}$ & 6.6 & $17.4 \mathrm{~b}$ & 5 \\
\hline A2P13 & $86.0 \mathrm{ab}$ & 6.9 & $19.6 \mathrm{~b}$ & 5 \\
\hline A2P16 & $79.4 \mathrm{c}$ & 7.5 & $17.4 \mathrm{~b}$ & 10 \\
\hline A3P4 & $80.0 \mathrm{c}$ & 7.2 & $19.8 \mathrm{~b}$ & 10 \\
\hline A4P15 & $86.0 \mathrm{ab}$ & 6.9 & $19.9 \mathrm{~b}$ & 10 \\
\hline A4P16 & $89.6 \mathrm{a}$ & 7.6 & $17.2 \mathrm{~b}$ & 5 \\
\hline A5P3 & $84.6 \mathrm{~b}$ & 6.8 & $20.4 \mathrm{ab}$ & 0 \\
\hline A5P3 & $79.0 \mathrm{c}$ & 6.5 & $18.4 \mathrm{~b}$ & 10 \\
\hline $\mathrm{K} 2 \mathrm{P} 5$ & $79.2 \mathrm{c}$ & 6.4 & $18.3 \mathrm{~b}$ & 10 \\
\hline K3P6 & $86.6 \mathrm{ab}$ & 6.9 & $18.6 \mathrm{~b}$ & 5 \\
\hline K4P9 & $88.3 \mathrm{a}$ & 7.5 & $17.8 \mathrm{~b}$ & 0 \\
\hline
\end{tabular}

This work suggests that several fluorescent pseudomonads isolates have the character of a phosphate solvent and nitrogen fixation. Phosphorus is one of the most important nutrients for plant growth. The majority of soil $\mathrm{P}$ is found in insoluble forms and only two soluble forms. the monobasic $\left(\mathrm{H}_{2} \mathrm{PO}_{4}{ }^{-1}\right)$ and the dibasic $\left(\mathrm{HPO}_{4}^{-2}\right)$ ions.thatcan be absorbed by plants (Bhattacharyya and Jha. 2012). Phosphate-solubilizing bacteria are considered promising biofertilizers since they can increase the availability of $\mathrm{P}$ to plants. Rhizobacteria released organic acids into the soil which solubilize the phosphate complexes converting them into ortho-phosphate which is available for plant uptake and utilization (Oteino et al. 2015). The ability of fluorescent pseudomonads isolates to fix nitrogen can directly increase plant growth. Pseudomonas strains can also benefit plant growth by providing plants with macro-and micro-nutrients, including nitrogen, iron, and phosphorus (Pieterse et al. 2014).

The indirect effect of fluorescent pseudomonads on rubber plant growth occurred because the bacteria were able to protect plant roots from the colonization of the fungus $R$. lignosus which can damage the roots, thereby disrupting the function of the roots in absorbing nutrients. $R$. lignosus penetrates the root system and colonizes the tissues. The mycelium of the pathogen degrades the host's cell structures. The pathogen of $R$. lignosus must repeatedly carry out penetration and colonization of their host cell wall by enzymatic digestion of the tissues characterized by differentiation of specialized structures ((Kaewchai and Soytong 2010).
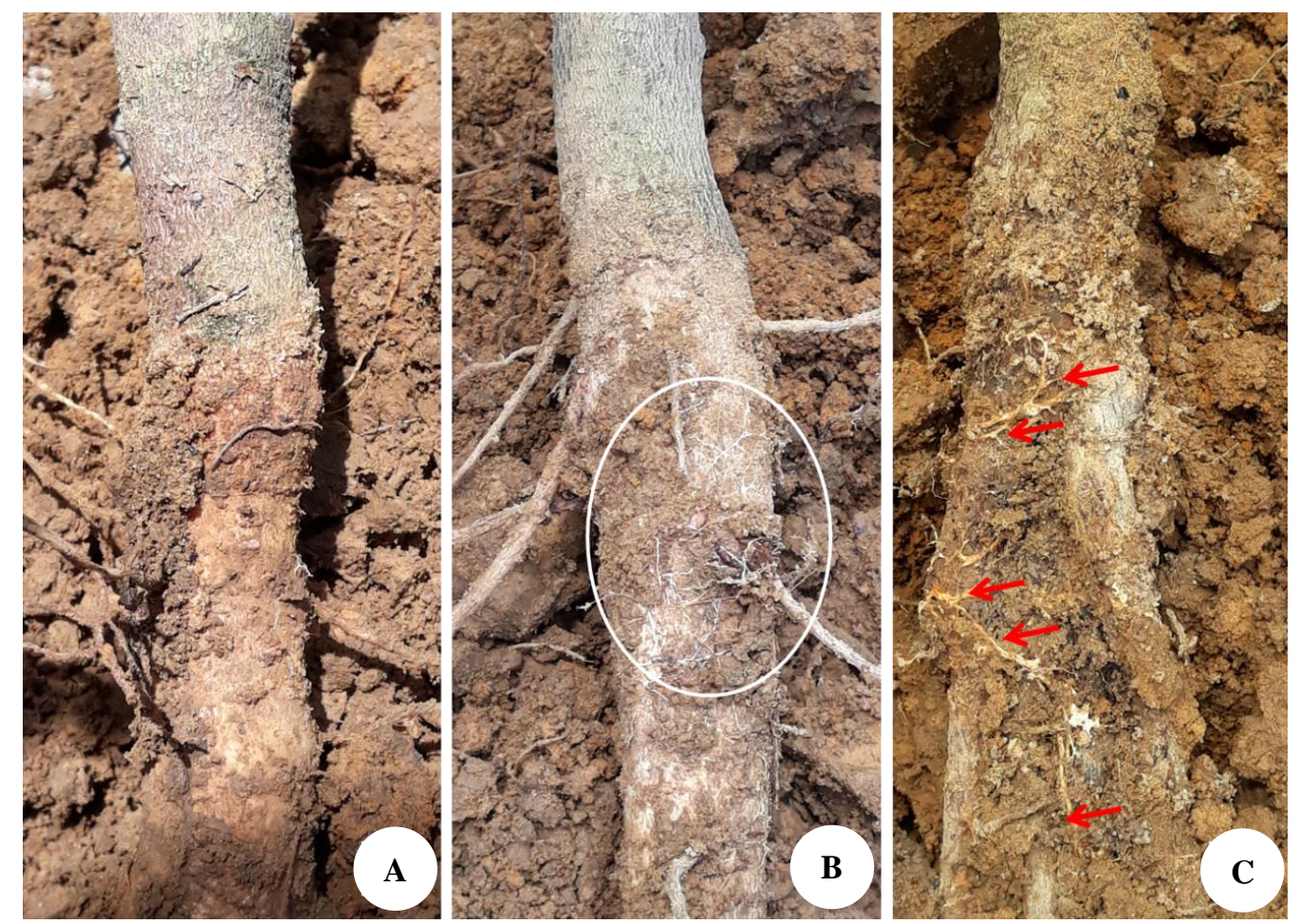

Figure 2. Effect of pseudomonads fluorescent isolate application on the colonization of $R$. lignosus on the roots of rubber plants: A. The root parts of plants were not found in the fungal colony of $R$. lignosus (healthy plants); $\mathrm{B}$. White rhizomorph of the $R$. lignosus on the root neck (white circle). the part of the plant above the soil surface has not shown any disease symptoms; C. Brownish rhizomorphs found in all plant roots (red arrows) 
Result showed that the application of fluorescent pseudomonads to rubber seedlings before planting was able to maintain plant growth. Application before planting had an effect on plant height and root weight at 9 months after planting, but had no effect on plant stem diameter (Table 3). This was also able to protect the roots from the colonization of the pathogen. The $R$. lignosus colonization in rubber plant without fluorescent pseudomonads treatment (negative control)was $65 \%$ compared to $0-10 \%$ in fluorescent pseudomonads treatment. Moreover, 35\% rubber plants were dead in negative control compare to 0 $5 \%$ of rubber plants in fluorescent pseudomonads treatment. Almost all root parts of the negative control plants showed $R$. lignosus rhizomorphs and some were brownish, causing the above-ground plant parts to show symptoms of wilting, yellowing, and falling leaves. There is some rubber plant with fluorescent pseudomonads treatment and without showed $R$. lignosus rhizomorph on the roots neck (Figure 2 ).

\section{REFERENCES}

Anees M, Abid M, Rehman S, Ahmed N, Ashraf M, Zhang L, Kim KY. 2019. Antifungal activity of various chitinolytic bacteria against Colletotrichum in pepper. Plant Protect Sci 55: 109-115.

Bakker PAHM, Berendsen RL, Doornbos RF, Wintermans PCA, Pieterse CMJ. 2013. The rhizosphere revisited: root microbiomics. Front Plant Sci 4: 165 .

Beier S, Bertilsson S. 2013. Bacterial chitin degradation-mechanisms and ecophysiological strategies. Front Microbiol 4: 49.

Beneduzi A, Adriana A, Luciane MPP. 2012. Plant growth-promoting rhizobacteria (PGPR): Their potential as antagonists and biocontrol agents. Gen MolBiol 35 (4): 1044-1051.

Bhattacharyya PN, Jha DK. 2012. Plant growth-promoting rhizobacteria (PGPR): emergence in agriculture. World J Microbiol Biotech 28: 1327-1350.

Charlotte Frydenlund Michelsen and Peter Stougaard. 2011. A Nove Antifungal Pseudomonas fluorescens Isolated from Potato Soils in Greenland. CurrMicrobiol (62): 1185-1192.

Damiri N, Mulawarman, Effendi RS. 2019. Antagonism of Pseudomonas fluorescens from plant roots to Rigidoporus lignosus pathogen of rubber white roots in vitro. Biodiversitas 20: 1549-1554.

de Vrieze M, Germanier F, Vuille N, Weisskopf L. 2018. Combining different potato associated Pseudomonas strains for improved biocontrol of Phytophthora infestans. Front Microbiol 9:2573.

Directorate General of Plantation. 2016. JAP Control on Rubber Plants in Indonesia with 2016 State Budget Fund. Article Technology.Ministry of Agriculture. Jakarta. [Indonesian]

Edi-PremonoM, Moawad AM, Vlek PLG. 1996. Effect of phosphatesolubilizing Pseudomonas putida on the growth of maize and its survival in the rhizosphere. Indon J Crop Sci 11: 13-23.

Gray EJ, Smith DL. 2005. Intracellular and extracellular PGPR: Commonalities and distinctions in the plant-bacterium signaling processes. Soil Biol Biochem 37: 395-412.

Haas D, Defago G. 2005. Biological control of soil-borne pathogens by fluorescent pseudomonads. Nature RevMicrobiol 4: 307-319

Harca NN, Mubarik NR, Wahyudi AT. 2014. Isolation and identification of nitrogen-fixing and Indole Acetic Acid-producing bacteria from oil plantation in Jambi, Indonesia. J Int Environ Appl Sci 9 (4): 546-553.

Hasanuddin. 2011. Antibiosis activity test of fluorescent pseudomonads against Rigidoporus lignosus (Klotszch) Imazeki the caused agent of white root disease. J HPT Trop 11 (1): 87-94.

Hernández-Leon R, Rojas-Solís D, Contreras-Pérez M, del Carmen Orozco-Mosqueda M, Macías-Rodríguez LI, Reyes-de la Cruz H, Valencia-Cantero E, Santoyo G. 2014. Characterization of the antifungal and plant growth-promoting effects of diffusible and volatile organic compounds produced by Pseudomonas fluorescens strains. Biol Cont 81: 83-92.
Herrmann L, Lesueur D, Brau L, Davison J, Robain H, Robin A, Vasar, Wiriyakitnateekul W, Opik M. 2016. Diversity of root-associated arbuscular mycorrhizal fungal communities in a rubber tree plantation chronosequence in Northeast Thailand. Mycorrhiza 26: 863-877.

Kaewchai S, Soytong K. 2010. Application of biofungicides against Rigidoporus microporus causing white root disease of rubber tree. $\mathrm{J}$ Agric Tech 6: 349-363.

Kamilova F, Validov S, Azarova T, Mulders I, Lugtenberg B. 2005. Enrichment for enhanced competitive plant root tip colonizers selects for a new class of biocontrol bacteria. Environ Microbiol 7: 18091817.

Khaeruni A, SutariatiGAK, Wahyuni S. 2010. Characterization and activities assay of rhizosphere bacteria from ultisol land for plantgrowth-promoting and biocontrol agents of soil-borne fungus pathogens under in vitro test. J HPT Trop 10 (2): 123-130.

Lingappa Y, Lockwood JL. 1962. Chitin media for selective isolation of actinomycetes. Phytopathology 52:317-323.

Manikandan R. Saravanakumar D. Rajendran L. Raguchander T.Samiyappan R. 2010. Standardization of liquid formulation of Pseudomonas fluorescens Pf1 for its efficacy against Fusarium wilt of tomato. Biol Cont 30: 1-8. DOI: 10.1016/j.biocontrol.2010.04.004.

Marwan H, Sinaga MS, Giyanto, Nawangsih AA.2011. Isolation and selection of endophytic bacteria to control blood disease on banana. J HPT Trop 11 (2): 113-121.

Mia MB. Shamsuddin Z. Mahmood M. 2010. Use of plant growthpromoting bacteria in banana: a new insight for sustainable banana production. Intl J Agric Biol 12 (3): 459-467

Michelsen CF, Stougaard P. 2011. A Novel Antifungal Pseudomonas fluorescens Isolated from potato soils in Greenland. Curr Microbiol 62: 1185-1192.

Mohanram S, Kumar P. 2019. Rhizosphere microbiome: revisiting the synergy of plant-microbe interactions. Annals Microbiol 69: 307-320.

Mohd FA, Lee SS, Maziah Z, Patahayah M. 2009. Pathogenicity of Rigidoporus microporus and Phellinus noxius against four major plantation tree species in Peninsular Malaysia. J Trop For Sci 21: 289298.

NandrisD. Nicole M. Geiger JP. 1987. Root rot diseases of rubber trees. Plant Dis 71: 298-306.

Nasrun, Nurmansyah. 2015. Potency of rhizobacteria and botanical fungicides to control white root fungus disease in rubber plants. J Indon Beverage Crops 2 (2): 61-68.

Nihorimbere V, Ongena M, Smargiassi M, Thonart P. 2011. Beneficial effect of the rhizosphere microbial community for plant growth and health. Biotechnol Agron Soc Environ 15 (2): 327-337

Oteino N, Lally RD, Kiwanuka S, Lloyd A, Ryan D, Germaini KJ, Dowling DN. 2013. Plant growth promotion induced by phosphate solubilizing endophytic Pseudomonas isolates. Front Microbiol 6: 745.

Panpatte DG, Jhala YK, Shelat HN, Vyas RV. 2016. Pseudomonas fluorescens: A promising biocontrol agent and PGPR for sustainable agriculture. In: Singh DP, Singh HB, Prabha R (eds.). Microbial Inoculants in Sustainable Agricultural Productivity Vol. 1: Research Perspectives. Springer, Nederland. DOI: 10.1007/978-81-322-2647-5_15

Paul DP, Sinha SN. 2016. Isolation and characterization of phosphate solubilizing bacterium Pseudomonas aeruginosa KUPSB12 with antibacterial potential from river Ganga, India. Ann Agra Sci 15 (1): 130-136.

Pierson III LS, Pierson EA. 2007. Roles of diffusible signals in communication among plant-associated bacteria. Phytopathology 97 : 227-232.

Pieterse CM, Zamioudis C, Berendsen RL, Weller DM, Van Wees SC, Bakker PA. 2014. Induced systemic resistance by beneficial microbes. Ann Rev Phytopathol 52: 347-375.

Ross IL. Alami Y. Harvey PR. Achouak W. Ryder MH. 2000. Genetic diversity and biological control activity of novel species of closely related pseudomonads isolated from wheat field soils in South Australia. Appl Environ Microbiol 66:1609-1616.

van den Broek D. Chin-A-Woeng TFC. Eijkemans K. Mulders IHM. Bloemberg GV. Lugtenberg BJ. 2003. Biocontrol traits of Pseudomonas spp. are regulated by phase variation. Mol PlantMicrob Interact 16:1003-1012.

Vanitha S, Ramjegathesh R. 2014. Bio Control Potential of Pseudomonas fluorescens against coleus root rot disease. J Plant Pathol Microb 5: 216.

Zou XH, Nonogaki H, Welbaum GE. 2002. A gel diffusion assay for visualization and quantification of chitinase activity. JMol Biotech22(1):19-27 